DOI: $10.14451 / 1.169 .70$

\title{
ИССЛЕДОВАНИЕ ИНТЕНСИВНОСТИ РОСТА ПРОДОВОЛЬСТВЕННЫХ ТОВАРОВ В РЕГИОНАХ ЦЕНТРАЛЬНОГО ФЕДЕРАЛЬНОГО ОКРУГА (ЦФО) *
}

\author{
(c) 2018 Соловьева Татьяна Николаевна \\ кандидат экономических наук, профессор \\ Курская государственная сельскохозяйственная академия им. И.И. Иванова \\ 305021, г. Курск, ул. К. Маркса, д. 70 \\ (c) 2018 Зюкин Данил Алексеевич \\ кандидат экономических наук \\ Курский государственный университет \\ 305000, г. Курск, ул. Радищева, д. 33 \\ E-mail: nightingale46@rambler.ru
}

В Российской Федерации реализуется активная политика по импортозамещению в сельскохозяйственном производстве. В работе проводится анализ изменения объемов производства сельскохозяйственной продукции в динамике за 2013-2017 гг. В исследовании уделяется особое внимание анализу производства продукции растениеводства и животноводства в ЦФО, как в регионе, лидирующем по объемам производства сельскохозяйственной продукции в стране. В результате исследования было установлено, что среди регионов-лидеров резервы для роста производства, как растениеводства, так и животноводства, еще не исчерпались, а неблагоприятные регионы в плане развития сельского хозяйства либо регрессируют, либо показывают крайне низкую восприимчивость к мерам поддержки сельского хозяйства, проявляющиеся в низких или темпах прироста объемов производства.

Ключевые слова: сельское хозяйство, импортозамещение, сельскохозяйственное производство, растениеводство, животноводство.

Обеспечение продовольственной безопасности является ключевой задачей развития экономики страны. В соответствии с Доктриной продовольственной безопасности Российской Федерации [1] государственная политика должна быть направлена на надежное обеспечение населения страны продовольствием, устойчивое развитие сельскохозяйственного производства, быстрое реагирование на внешние и внутренние угрозы стабильности продовольственного рынка, а также на эффективное международное взаимодействие и сотрудничество в сфере продовольственной безопасности. Основными видами продукции сельскохозяйственного производства, по которым обязаны обеспечиваться пороговые значения производства в рамках доктрины продовольственной безопасности, являются зерно, сахар, растительное масло, мясо и мясопродукты, молоко и молокопродукты, рыбная продукция, картофель и соль пищевая.

Еще пятнадцать лет назад Российская Федерация импортировала втрое больше мяса и мясопродуктов, чем в 2017 г., а постепенный переход к политике импортозамещения на продовольственном рынке мог продолжаться гораздо дольше, если бы ответные контрсанкции в форме продовольственного эмбарго со стороны нашей страны. Однако такое решение требует от государства обеспечения реализации мероприятий, направленных на скорейшее замещение рыночной ниши на российском агрорынке, которую занимали страны, попавшие под действие эмбарго.

Чтобы эту ниши заняли отечественные агропроизводители, а импортозамещение продовольствия действительно осуществлялось, по нашему мнению, необходимо совершенствование механизма государственного и экономического регулирования, в рамках которого государственная поддержка будет стимулирующий, а не компенсационный характер, а также будут созданы благоприятные условия для инвестиций в аграрный сектор экономики [2]. Алтухов А.И. [3] считает, что качественно новая аграрная политика государства способна обеспечить стабильность и развитие агропродовольственного сектора и

* Статья подготовлена при финансовой поддержке РФФИ в рамках научного проекта № 18-310-00211 
послужить исполнению основных целей и задач доктрины продовольственной безопасности.

Наши исследования в вопросах развития зернопродуктового подкомплекса $[4,5]$ свидетельствуют о том, что Россия, являясь одним из крупнейших экспортеров зерна в мире, не может обеспечить переходе к инновационному типу развития этого системообразующего элемента АПК, который значительно влияет на хлебофуражное обеспечение страны. Аналогичная ситуация возникла и в отношении свеклосахарного подкомплекса - другого аграрного направления, по которому превышается порог обеспеченности по Доктрине и имеются предпосылки наращивания экспорта [6, 7].

Существенной проблемой в условиях эмбарго стало решение вопросов обеспечения животноводческой продукцией, в особенности молочной продукцией, поскольку существовавшая долгие годы система сельскохозяйственного производства в России устарела, поэтому до введения продовольственного эмбарго конкурировать отечественным производителям с зарубежными было достаточно сложно как в вопросах цены, так и в вопросах качества продукции $[8,9]$.

Отразить, как развивается отечественное сельскохозяйственное производство в условиях импортозамещения, можно с помощью анали- за изменения объемов сельскохозяйственного производства. За последние 5 лет объемы производства сельскохозяйственной продукции возросли на 53,3\%, в том числе на 58,1\% увеличилось растениеводство, а на 48,2\% животноводство. Но стоит отметить, что темпы прироста в 2014-2015 гг. были значительно выше, чем в 2017 г. Если в 2014-2015 гг. темп прироста сельскохозяйственного производства составил 17,1\% и 19,5\% соответственно, то в 2016 г. его величина оказалась равна 6,5\%, а в 2017 г. - 2,7\%. Причем растениеводство в 2015 г., когда было принято решение о введении продовольственного эмбарго, показало более резкий рост $(25,6 \%)$, чем животноводство (13,2\%), а в 2017 г. в растениеводстве относительно предыдущего года наметилось снижение на $0,1 \%$, в то время как животноводство продолжило показывать рост (рисунок 1).

Как известно, уровень территориального социально-экономического развития в федеральных округах Российской Федерации значительно различается. Поэтому отличается и уровень развития сельскохозяйственного производства, во многом обуславливаемый природно-климатическими условиями и финансовыми возможностями регионов. Проанализируем место и изменение доли федеральных округов в общем

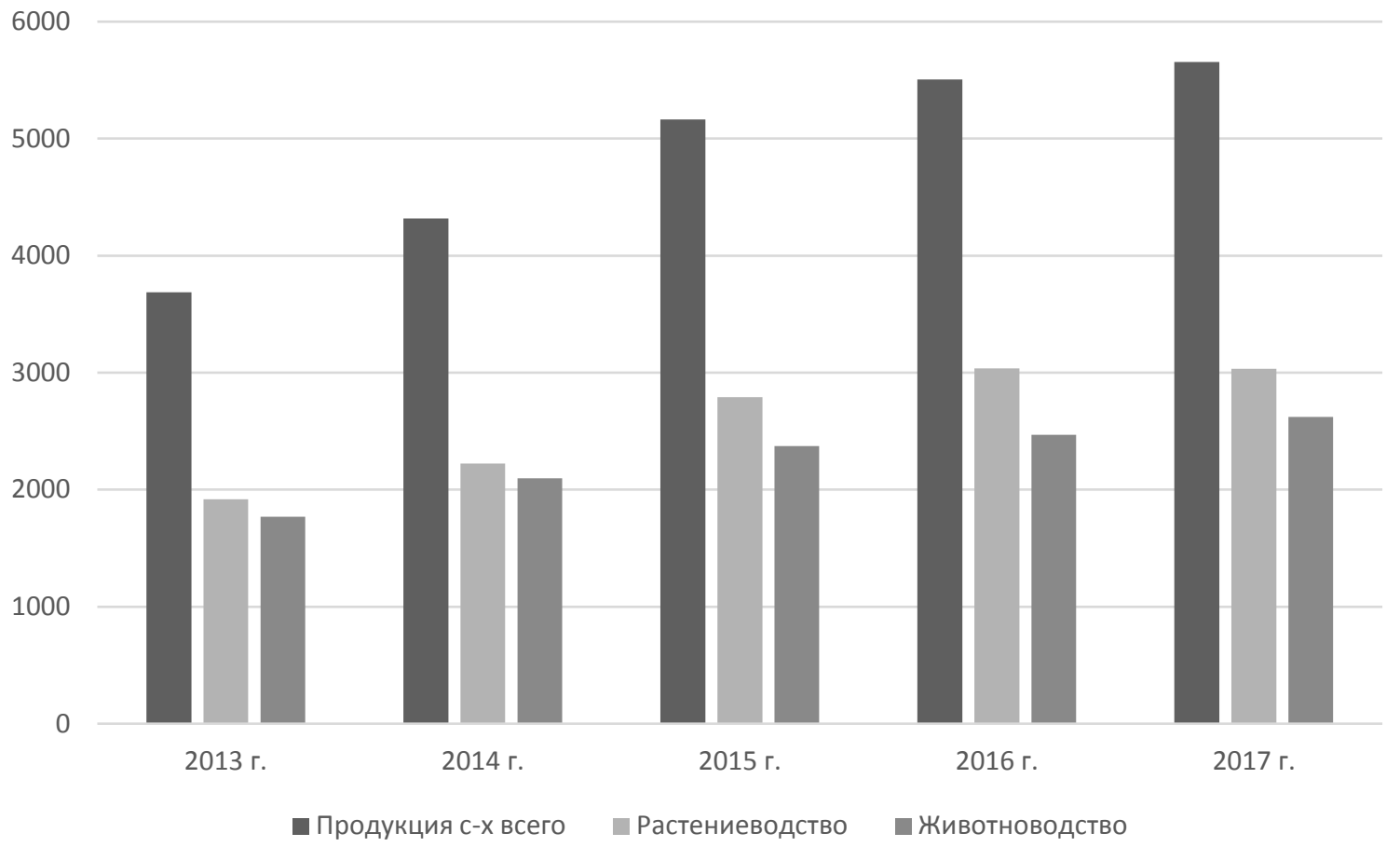

Puc. 1 - Объемы производства сельскохозяйственной продукции в РФ, млрд. руб. Источник: Составлено автором на основе данных статистического сборника Регионы России [10] 
объеме производства сельскохозяйственной продукции в табл. 1.

Первое место в структуре объемов производства сельскохозяйственной продукции занимает ЦФО - более 25\% от общего объема, увеличивший в динамике собственную долю на 0,6\%. Второе место приходится на ПФО, где производится более $23 \%$ объема, т.е. на две территориальных единицы приходится почти половина всей производимой в России сельскохозяйственной продукции. Наибольший прирост в структуре производства сельскохозяйственной продукции показал ЮФО, занимавший на протяжении всего периода третье место, доля которого возросла с $15,4 \%$ до 17,4\%. Положительная динамика по приросту доля в структуре производства сельскохозяйственной продукции наблюдается в СКФО, доля которого превышает УФО, хотя площади занимаемой территории значительно различаются, и ДФО, производящем наименьший объем сельскохозяйственной продукции на фоне стране. Наибольшую отрицательную динамику в структуре показали СФО - сокращение составило 2,3\%; в ПФО показатель сократился на 0,6\%, СЗФО и УФО сокращение оказалось незначительным.

Таким образом, в ЦФО сконцентрировано свыше четверти аграрного производства страны, а также это наиболее густонаселенный и финансово обеспеченный округ Российской Федерации, поэтому от процессов наращивания там аграрного производства в высокой мере зависит решение задач импортозамещения продовольствия. К тому же географическое положение и природно-экономический потенциал округа с исторически сложившейся концентрацией промышленного производства на его территории способствуют ускорение процесса импортоза- мещения.

Успешное развитие сельскохозяйственного производства на территории ЦФО во многом происходит за счет того, что на его территории располагается Центральное Черноземье, славящееся плодородием почв, на территории которого расположены 5 регионов ЦФО. В первую очередь, стоит рассмотреть, как изменились объемы производства продукции растениеводства, поскольку основными видами растений, от которых зависит продовольственная безопасность России, являются зерновые и сахарная свекла, активно возделываемые на территории ЦФО (табл. 2).

Лидером по производству растениеводческой продукции в ЦФО является Воронежская область, причем в среднем объемы производства в 1,7 раза превышают показатели второго региона по объемам производства продукции растениеводства - Курской области. К регионам, производящим крупные объемы продукции растениеводства можно отнести Белгородскую, Тамбовскую, Липецкую и, как ни странно, Московскую область, где делается упор на интенсификацию производства, а не на природные особенности почв, как в регионах Центрального Черноземья. Стоит так же отметить неэффективность Ивановской области в производстве продукции растениеводства, которая производит столько же, сколько и Москва. Низкие объемы производства продукции растениеводства характерны так же для Костромской, Ярославской, Смоленской и Тверской областей. Рассматривая динамику развития показателя, мы видим, что в ряде регионов наблюдается снижение объемов производства продукции растениеводства - Владимирская, Ивановская, Костромская, Ярославская, Смоленская и Тверская области и

Таблица 1. Доля федеральных округов РФ в структуре производства сельскохозяйственной продукции в 2013-2017 гг.,\%

\begin{tabular}{|c|c|c|c|c|c|c|}
\hline $\begin{array}{c}\text { Федеральный } \\
\text { округ }\end{array}$ & 2013 г. & 2014 г. & 2015 г. & 2016 г. & 2017 г. & Изменение, \% \\
\hline ЦФО & 24,8 & 25,4 & 26,0 & 25,6 & 25,5 & 0,7 \\
\hline СЗФО & 4,7 & 4,9 & 4,7 & 4,4 & 4,4 & $-0,3$ \\
\hline ЮФО & 15,4 & 16,3 & 17,2 & 17,6 & 17,4 & 2,0 \\
\hline СКФО & 8,1 & 7,9 & 7,9 & 8,4 & 8,6 & 0,5 \\
\hline ПФО & 23,9 & 23,4 & 22,9 & 23,5 & 23,3 & $-0,6$ \\
\hline УФО & 6,4 & 6,2 & 6,0 & 6,0 & 6,3 & $-0,1$ \\
\hline СФО & 13,6 & 12,6 & 12,2 & 11,6 & 11,3 & $-2,3$ \\
\hline ДФО & 3,0 & 3,4 & 3,1 & 2,9 & 3,2 & 0,2 \\
\hline
\end{tabular}

Источник. Составлено автором на основе данных статистического сборника Регионы России [10]. 
Таблица 2. Объемы производства продукции растениеводства в регионах ЦФО, млрд. руб.

\begin{tabular}{|c|c|c|c|c|c|c|c|}
\hline \multirow{2}{*}{ Регион } & \multirow{2}{*}{2013 г. } & \multirow{2}{*}{2014 г. } & \multirow{2}{*}{2015 г. } & \multirow{2}{*}{2016 г. } & \multirow{2}{*}{2017 г. } & \multicolumn{2}{|c|}{ Изменение } \\
\hline & & & & & & $(+,-)$ & $\%$ \\
\hline Белгородская область & 48,8 & 53,4 & 69,9 & 79,3 & 69,8 & 21,0 & 43,0 \\
\hline Брянская область & 19,0 & 23,2 & 30,7 & 29,5 & 31,5 & 12,5 & 65,7 \\
\hline Владимирская область & 13,1 & 16,0 & 18,8 & 12,7 & 10,7 & $-2,4$ & $-18,4$ \\
\hline Воронежская область & 92,3 & 100,6 & 133,3 & 130,2 & 120,8 & 28,5 & 30,9 \\
\hline Ивановская область & 6,0 & 8,4 & 8,6 & 5,5 & 5,3 & $-0,7$ & $-12,0$ \\
\hline Калужская область & 13,5 & 15,6 & 19,3 & 15,0 & 17,1 & 3,6 & 26,5 \\
\hline Костромская область & 7,9 & 9,6 & 11,2 & 6,6 & 5,7 & $-2,2$ & $-28,1$ \\
\hline Курская область & 50,7 & 58,3 & 75,2 & 76,1 & 75,7 & 25,0 & 49,2 \\
\hline Липецкая область & 40,3 & 50,3 & 63,2 & 65,8 & 60,5 & 20,3 & 50,4 \\
\hline Московская область & 42,2 & 51,9 & 61,8 & 52,1 & 42,9 & 0,8 & 1,8 \\
\hline Орловская область & 28,8 & 35,4 & 44,8 & 47,9 & 38,6 & 9,8 & 34,0 \\
\hline Рязанская область & 22,7 & 27,0 & 32,6 & 29,5 & 29,2 & 6,6 & 29,1 \\
\hline Смоленская область & 9,2 & 9,0 & 11,5 & 8,1 & 7,9 & $-1,3$ & $-14,2$ \\
\hline Тамбовская область & 45,6 & 53,3 & 84,0 & 67,7 & 59,7 & 14,0 & 30,3 \\
\hline Тверская область & 9,4 & 9,2 & 11,5 & 7,6 & 6,9 & $-2,5$ & $-26,2$ \\
\hline Тульская область & 21,0 & 27,6 & 36,3 & 34,1 & 35,8 & 14,8 & 70,4 \\
\hline Ярославская область & 8,4 & 10,4 & 10,4 & 9,9 & 8,2 & $-0,2$ & $-2,4$ \\
\hline Москва & 6,1 & 6,8 & 7,1 & 6,1 & 5,9 & $-0,2$ & $-3,6$ \\
\hline
\end{tabular}

Источник. Составлено автором на основе данных статистического сборника Регионы России [10].

Москва, причем, быстрее остальных деградируют Костромская и Тверская области. В остальных регионах ЦФО наблюдается положительная динамика, а наибольший прирост продукции растениеводства показали Тульская и Брянская области. Примечательно, что, казалось бы, при высокой степени развития производства продукции растениеводства в регионах Черноземья, в них так же отмечаются высокие темпы прироста производства продукции растениеводства 30-50\% в отдельных областях.

Вторым столпом в обеспечении продовольственной безопасности страны является производство продукции животноводства. Объемы производства продукции животноводства в ЦФО рассмотрим в табл. 3.

Следует отметить, что динамика прироста в относительном выражении продукции животноводства выше во всех регионах ЦФО (кроме Тульской области), что как раз и свидетельствует о потребности занять рыночную нишу, освободившуюся после введения эмбарго коснувшуюся в первую очередь продукции животноводства. Лидирующие позиции по производству продукции животноводства не только в округе, но и в стране занимает Белгородская область, которая превосходит более чем в 2 раза и почти в 3 раза других лидеров ЦФО - Воронежскую и Курскую области. Другие области ЦЧР также показатели высокую динамику в абсолютном и относительном выражении и относятся к регионам лидерам в округе. Не считая Москвы, где нет условий для производства аграрной продукции, низкие объемы производства животноводческой продукции выявлены в Костромской, Ивановской и Смоленской областях. Максимально быстрые темпы роста производства животноводческой продукции наблюдаются в Брянской области $117 \%$, хотя в абсолютном выражении они производят втрое меньше лидера и в 2017 г. приблизились к уровню Курской и Тамбовской областей. Выше 100\% приросли объемы производства животноводческой продукции в Тверской области, позволив ей в 2017 г. опередить, помимо Московской, Костромской и Ивановской, еще 5 областей. Во всех регионах ЦФО динамика производства продукции животноводства положительная, наименьший прирост отмечается в Костромской области, где и без того ситуация с развитием животноводства неблагоприятная.

При этом сохраняются значительные резервы роста производства животноводческой продукции, так как состояние кормовой базы за счет рекордных урожаев зерновых полностью обе- 
Таблица 3. Объемы производства продукции животноводства в регионах ЦФО, млрд. руб.

\begin{tabular}{|l|c|c|c|c|c|c|c|}
\hline \multirow{2}{*}{ Регионы } & 2013 г. & 2014 г. & 2015 г. & 2016 г. & 2017 г. & \multicolumn{2}{|c|}{ Изменение } \\
\cline { 5 - 8 } & & & & & & $(+,-)$ & \multicolumn{2}{c|}{$\%$} \\
\hline Белгородская область & 106,6 & 134,8 & 150,7 & 146,7 & 157,4 & 50,9 & 47,7 \\
\hline Брянская область & 24,4 & 33,1 & 43,2 & 48,9 & 53,0 & 28,6 & 117,1 \\
\hline Владимирская область & 14,8 & 16,8 & 18,4 & 18,1 & 18,3 & 3,5 & 23,6 \\
\hline Воронежская область & 51,6 & 58,3 & 67,8 & 69,1 & 73,1 & 21,5 & 41,7 \\
\hline Ивановская область & 7,7 & 7,4 & 8,7 & 9,4 & 9,6 & 1,9 & 24,6 \\
\hline Калужская область & 13,0 & 15,7 & 18,0 & 18,5 & 21,4 & 8,5 & 65,6 \\
\hline Костромская область & 9,2 & 9,8 & 11,6 & 10,5 & 10,3 & 1,1 & 12,3 \\
\hline Курская область & 28,6 & 40,0 & 46,9 & 48,2 & 55,2 & 26,6 & 93,1 \\
\hline Липецкая область & 24,4 & 31,7 & 38,0 & 40,6 & 41,1 & 16,7 & 68,3 \\
\hline Московская область & 36,1 & 38,1 & 41,8 & 46,2 & 44,6 & 8,5 & 23,6 \\
\hline Орловская область & 14,2 & 17,0 & 19,8 & 20,6 & 21,9 & 7,7 & 54,2 \\
\hline Рязанская область & 16,2 & 19,0 & 21,8 & 21,5 & 23,0 & 6,9 & 42,5 \\
\hline Смоленская область & 11,0 & 12,9 & 12,8 & 13,2 & 15,0 & 3,9 & 35,5 \\
\hline Тамбовская область & 26,7 & 40,2 & 44,7 & 41,2 & 51,7 & 25,0 & 93,8 \\
\hline Тверская область & 13,3 & 15,3 & 20,8 & 25,2 & 28,0 & 14,6 & 109,8 \\
\hline Тульская область & 14,9 & 18,2 & 19,9 & 22,2 & 22,6 & 7,7 & 51,5 \\
\hline Ярославская область & 16,5 & 19,7 & 23,5 & 22,0 & 23,8 & 7,3 & 44,3 \\
\hline Москва & 2,0 & 2,6 & 2,7 & 2,4 & 2,6 & 0,6 & 30,9 \\
\hline
\end{tabular}

Источник. Составлено автором на основе данных статистического сборника Регионы России [10].

спечивает потребности растущего внутреннего зернового рынка, не смотря на увеличение объемов его экспорта. Несмотря на неблагоприятную макроэкономическую обстановку в стране, характеризующуюся высокой волатильностью рубля, труднодоступностью кредитных ресурсов и нехватку инвестиций, политика импортозамещения дает определенные положительные результаты. Это проявляется в увеличении объемов производства продукции растениеводства и животноводства. Как показали результаты анализ, лидируют по объемам производства обеих категорий сельскохозяйственной продукции в ЦФО регионы ЦЧР, обладающие высоким природно-экономическим потенциалом производства аграрной продукции. При этом интенсивное наращивание товарной стоимости продукции животноводства происходит во всех регионах ЦФО, тогда как стоимость товарной продукции растениеводства в некоторых областях сократилась.

Необходимо в дальнейшем обеспечить возможности дальнейшего наращивания продовольственной продукции до уровня порога безопасности, установленного в Доктрине, в особенности это касается мясо-молочной продукции. Важным компонентом является создание соответствующим потребностям реализации политики импортозамещения механизма экономического и государственного регулирования аграрной сферы. Также следует воспользоваться возможностями мультипликативных отраслей, например, зернопродуктового подкомплекса, развитие которого способно обеспечить конкурентные преимущества производства отечественной животноводческой продукции за счет качественной и дешевой кормовой базы.

\section{Библиографический список}

1. Указ Президента Российской Федерации от 30 января 2010 г. № 120 «Об утверждении Доктрины продовольственной безопасности Российской Федерации». Российская газета. [Электронный ресурс]. Режим доступа: https://rg.ru/2010/02/03/prod-dok.html (Дата обращения: 25.12.2018 г.).

2. Соловьева Т.Н. Государственное регулирование и импортозамещение продовольственной продукции: проблемы и решения / Т.Н. Соловьева, Н.А. Пожидаева, Д.А. Зюкин // Экономика сельскохозяйственных и перерабатывающих предприятий. 2016. № 11. С. 17-20. 
3. Алтухов А.И. Достижение продовольственной независимости страны на основе новой государственной аграрной политики // Региональный вестник. 2016. № 2. С. 2-5.

4. Зюкин Д.А. Состояние зернопродуктового подкомплекса АПК России в условиях расширения экономического пространства и продовольственного эмбарго // Азимут научных исследований: экономика и управление. 2018. Т. 7. № 3 (24). С. 100-103.

5. Соловьева Т.Н., Пожидаева Н.А. Инновационный подход к использованию природно-экономического потенциала зернового хозяйства // Вопросы социально-экономического развития регионов. 2016. № 1 . С. 10-15.

6. Святова О.В., Солошенко Р.В. Рынок сахара России: проблемы и перспективы // Вопросы социально-экономического развития регионов. 2017. № 1 (2). С. 2-7.

7. Святова О.В. Увеличение экспортного потенциала как направление повышения эффективности свеклосахарного подкомплекса АПК России // Вопросы социально-экономического развития регионов. 2016. № 1. С. 2-9.

8. Балакирев Н.А. Животноводство России в условиях импортозамещения // Достижения науки и техники АПК. 2016. № 3. С. 74-76.

9. Суханова И.Ф., Лявина М.Ю. Совершенствование системы господдержки животноводства как инструмента политики импортозамещения // Аграрный научный журнал. 2017. № 12. С. 92-95.

10. Регионы России. Социально-экономические показатели. [Электронный ресурс]. Режим доступа: http://www. gks.ru/wps/wcm/connect/rosstat_main/rosstat/ru/statistics/publications/catalog/doc_1138623506156 (Дата обращения: 25.12.2018 г.). 